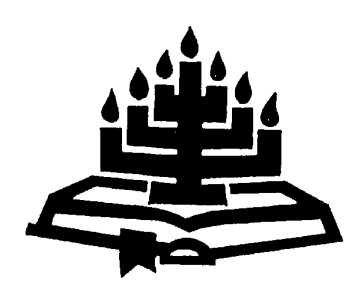

\title{
Die sosiale en praktiese implikasies van 2 Korintiërs 6:14 vir Christene in Suid-Afrika
}

\author{
G.J.C. Jordaan \\ Skool vir Bybeltale en Bybelwetenskappe \\ Potchefstroomse Universiteit vir CHO \\ POTCHEFSTROOM \\ E-pos: ontgjcj@puknet.puk.ac.za
}

\begin{abstract}
The social and practical implications of 2 Corinthians 6:14 for Christians in South Africa

The prohibition in 1 Corinthians not to be mismated with unbelievers is part of the metaphoric language by which Paul explains a principle for relations between believers and unbelievers. Evidence drawn from a grammatical and thought-structure analysis of the text as well as evidence drawn from its socio-historical context makes it clear that this prohibition is applicable to a variety of relations, especially marriage relations, labour and business relations, religious relations and even political relations. The prohibition should not lead Christians into an ascetic lifestyle, but should rather exhort them to establish such relationships with unbelievers that their own holiness as body of Christ will remain untouched. In all relations believers should refrain from taking any other yoke upon themselves than the yoke of our Lord Jesus. Finally, all relations with unbelievers should be upheld with the missionary purpose of bringing such unbelievers to the faith of the Lord.
\end{abstract}

\section{Inleiding}

In 2 Korintiërs 6:14 is 'n vermaning gerig aan die gelowiges in Korinte: "Moenie in dieselfde juk trek saam met ongelowiges nie". Uit die konteks van hierdie frase blyk dat hierdie vermaning verband hou met die verhouding tussen gelowiges en ongelowiges, en bepaalde optrede van die gelowiges verbied.

Christene in Suid-Afrika raak al meer daarvan bewus dat hulle tussen ongelowiges leef. Aangesien 2 Korintiërs 6:14 'n vermaning bevat oor hoe met ongelowiges omgegaan moet word, is dit vir Christene belangrik om so noukeurig as moontlik vas te stel watter optrede in hierdie Skrifdeel verbied word, sodat God daarin gehoorsaam kan word. 
Die vermaning van 2 Korintiërs 6:14 is in metaforiese taal gestel ("in een juk trek"). Die betekenis en die toepassing van die metafoor is nie voor die hand liggend nie. Gevolglik is daar by navorsers meningsverskil oor die betekenis en die strekwydte van die praktiese toepassing daarvan.

Sommige navorsers beskou hierdie metafoor as 'n algehele verbod op gemeenskaplike optrede van gelowiges met ongelowiges (Grosheide, 1974:94; Wolff, 1989:149); ander reken dat gesamentlike optrede, byvoorbeeld in die sakesektor, wel moontlik is, maar dat gelowiges daarin nie met die ongelowige manier van doen mag saamgaan nie (Filson \& Reid, 1953:352). Meyer (1879:276) en Carrez (1986:165) verklaar die verbod so dat dit wel moontlik is om verbintenisse aan te gaan, net solank dit nie 'n ongelyke verbintenis is nie, met ander woorde verbintenisse waarin die heidene die sterker vennoot is nie. Heelwat navorsers verklaar die metafoor as ' $n$ verbod bloot met betrekking tot deelname aan heidense feeste en ander goddelose heidense praktyke (Calvyn, 1979:257; Kruse, 1991:136). Die uitleg van ouer verklaarders, naamlik dat dit bloot 'n verbod op gemengde huwelike tussen gelowiges en ongelowiges is, word blykbaar nie meer deur jonger verklaarders oorweeg nie (vgl. Plummer, 1948:206).

Wat die probleem verder kompliseer, is die feit dat sommige teoloë die outentisiteit van 2 Korintiërs 6:14-7:1 betwis. Skrywers soos Duff (1993:160$180)$ en Sass (1993:36-64) is van mening dat hierdie verse nie in die konteks van 2 Korintiërs 6 en 7 inpas nie en daarom 'n latere nie-Pauliniese interpolasie is. Sodanige argumentering lei tot die vraag of dit hoegenaamd geldig is om 2 Korintiërs 6:14 op die Christen se huidige leefwêreld te probeer betrek.

Daarmee saam ontstaan die vraag of hierdie vermaning, as dit wel outentiek is, enigsins as blywende opdrag aan gelowiges van alle tye bedoel is en of dit bloot gerig was op die onmiddellike situasie van die destydse gelowiges in Korinte.

Hieruit volg dat 'n studie van 2 Korintiërs 6:14 nodig is ten einde die volgende vrae te betrek:

- Is 2 Korintiërs 6:14 'n outentieke vermaning van die apostel Paulus in sy brief aan die Korintiërs?

- Hoe sou die destydse Korintiërs die simboliek van "in een juk trek" verstaan het?

- Is 2 Korintiërs 6:14 'n vermaning wat bedoel is vir Christene van alle tye, ook vir Christene in Suid-Afrika vandag?

- Hoe kan en moet die hedendaagse Christen die vermaning om nie in een juk met ongelowiges te trek nie op die Suid-Afrikaanse situasie van toepassing mak? 
Saamgevat sentreer die navorsingsprobleem in die volgende vraag: mag die hedendaagse Christen 2 Korintiërs 6:14 op die verhouding tussen gelowiges en ongelowiges in Suid-Afrika toepas, en indien wel, hoe?

Die doel van dié artikel is om te bepaal of 2 Korintiërs 6:14 lig werp op die verhouding tussen gelowiges en ongelowiges in Suid-Afrika vandag en, indien wel, watter lig dit op die verhouding werp. Met die oog op hierdie doel en ter beantwoording van bogenoemde vrae word die volgende werkswyse gevolg:

- Die vraag na die outentisiteit van 2 Korintiërs 6:14 is terselfdertyd 'n vraag na die samehang van hierdie vers met die res van die brief. Ten einde die samehang van hierdie vers met die res van die brief te bepaal, word die strukturele opbou van die brief en sy onderdele vasgestel, met besondere aandag aan die plek van 2 Korintiërs 6:14 binne sy onmiddellike konteks. Hierdie ontleding word gedoen in ooreenstemming met die metode van gedagtestruktuurontleding soos uiteengesit deur Coetzee (1988:19-36).

- Ten einde beter te begryp hoe die destydse Korintiërs die beeld van "in een juk trek" sou verstaan het, word aan die hand van literatuurstudie inligting versamel oor die betekenis van die beeld "in een juk trek" binne die sosiohistoriese leefwêreld van die Korintiërs.

- In die lig van die gedagtestruktuurontleding, en in samehang met 'n sintaktiese, semantiese en stilistiese ontleding van 6:14, word getrag om vas te stel of 6:14 as ' $n$ bloot situasiegerigte opdrag bedoel was of as 'n opdrag vir alle tye.

- Uit 'n sintese van die resultate van die eerste twee stappe word die draagwydte en implikasies van die verbod vir die Korintiërs geformuleer. Verder word die draagwydte van die verbod gedefinieer deur dit te stel in die lig van die algemene eise van geloofsgehoorsaamheid en die gelowige se roeping ten opsigte van heidene soos elders in die Skrif geopenbaar. Dit word gedoen met behulp van 'n proses van Skrif-met-Skrif-vergelyking.

- Ten einde die toepaslikheid van hierdie verbod op die hedendaagse SuidAfrikaanse situasie aan te toon, word in die proses van hermeneuse

- 'n kort analise gemaak van die huidige situasie in Suid-Afrika ten opsigte van die verhouding tussen gelowiges en ongelowiges, en

- raakpunte geïdentifiseer tussen die huidige situasie en die draagwydte van die verbod, en die verbod in 6:14 sodoende toegepas op die praktiese omgang van Christene met ongelowiges in Suid-Afrika vandag. 


\section{Die verhouding tussen 2 Korintiërs 6:14 en die res van die brief}

Verskeie biblioloë reken dat 2 Korintiërs nie 'n sterk struktuur vertoon nie (vgl. Kümmel, 1972:206; Guthrie, 1990:457; Coetzee, 1995:40). Die brief word gekenmerk deur abrupte oorgange en gedeeltes wat op die oog af nie met mekaar saamhang nie. Daarom word daar uit verskeie oorde twyfel oor die eenheid van hierdie brief uitgespreek (Lategan, 1984:89). Volgens Kümmel (1972:211) blyk dit dat biblioloë soos Jülicher, Bultmann, Dinkler, Bornkamm, Georgi, Fitzmyer en in 'n mindere mate Schmithals, 2 Korintiërs as 'n konglomeraat van Pauliniese en nie-Pauliniese materiaal beskou.

Kümmel (1972:211) wys hierdie beskouing egter oortuigend af deur aan te toon dat nóg historiese nóg taalkundige argumente afdoende bewyse kan lewer dat die teks van 2 Korintiërs of dele daarvan van nie-Pauliniese oorsprong is nie (vgl. ook Duff, 1993:172). Hierby moet die feit gemeld word dat daar tekskrities geen aanduidings is dat hierdie brief ' $n$ samestelling van 'n verskeidenheid van materiaal is nie. Selfs die vroegste teksgetuies $\left(\mathrm{P}^{46}- \pm 200\right.$ n.C., Tertullianus 220 n.C.) bevat die brief as eenheid soos dit deur die eeue oorgelewer is, sonder 'n aanduiding van enige latere interpolasies. Gevolglik kan die eenheid van 2 Korintiërs met goeie wetenskaplike grond gehandhaaf word.

\subsection{Die gedagte-opbou van die brief}

Die erkenning van die eenheid van 2 Korintiërs los egter nog nie die probleem van die los struktuur van die brief op nie. Die feit dat soveel onderdele van die brief nie tematies aan die onmiddellike konteks verbind is nie (bv. 2:14-7:4, en daarbinne weer 6:14-7:2, en later weer hoofstukke 8 en 9 as geheel) is ook deur kritiese teoloë gebruik om die outentisiteit van die brief in twyfel te trek. Kümmel (1972:214) dui egter aan dat die onsamehangende struktuur nie as sodanig 'n bewys is van interpolasie nie. Verskeie ander verklarings vir so 'n struktuur kan aangebied word.

Van die verklarings wat aangebied word, is dié van Guthrie (1990:457) myns insiens die aanvaarbaarste verklaring, naamlik dat 2 Korintiërs nie by 'n enkele geleentheid geskryf is nie, maar met heelwat onderbrekings en verposings opgestel is. Oor die oorsake van sulke onderbrekings kan maar net bespiegel word. Moontlik het Paulus die brief reeds begin skryf voor sy vertrek uit Efese, tydens sy reis na Europa verder geskryf, by sy aankoms in Filippi weer daaraan toegevoeg (waarskynlik hoofstukke 8 en 9), en die res geskryf terwyl hy weer op reis was.

In weerwil van die oënskynlik los struktuur is daar tog enkele woorde en frases wat by herhaling in die brief voorkom en wat 'n koherensie van die brief as geheel aandui: 
- Die verwysings na Titus wat by herhaling in die loop van die brief opduik, is opvallend: $2: 12-13 ; 7: 5-16 ; 8: 16-23 ; 12: 18$. Hierdie patroon versterk die vermoede dat Paulus die brief geskryf het terwyl hy op reis was, aangesien die reëlings met betrekking tot die bewegings van en reëlings in verband met sy helper Titus as 't ware die "ruggraat" van die brief vorm.

- Wat ook as merker beskou kan word, is die herhaalde verwysings na (self-)

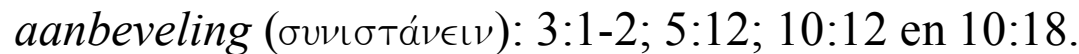

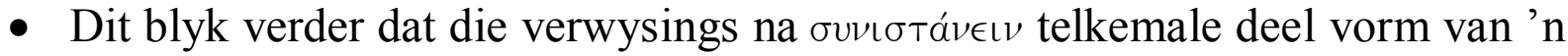

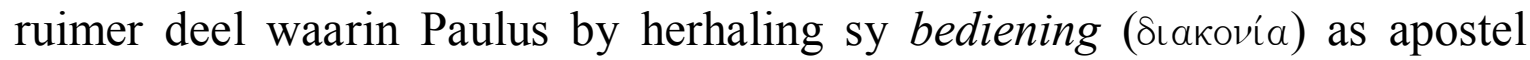
verdedig. Die dele waarin sıakovía en semanties verwante woorde sterk na vore tree, is $2: 14-7: 4$ en 10:1-12:21.

- Laasgenoemde twee dele het elkeen bepaalde temawoorde wat by herhaling daarin voorkom:

- In 2:14-7:4 word die bediening in verband gebring met die nuwe en die ou verbond (3:6-18), die vernuwing van die ou sterflike liggaam (4:7-17) en die versoening met God (5:18-7:4). Sleuteluitdrukkings is dan ook: die bediening van die nuwe verbond (3:6), die bediening van die dood/ van die Gees (3:7-8) en die bediening van die versoening (5:18).

- In 10:1-12:21 bring Paulus sy bediening weer by herhaling in verband met

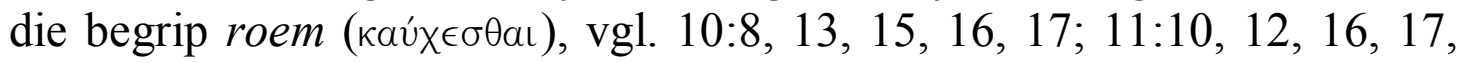

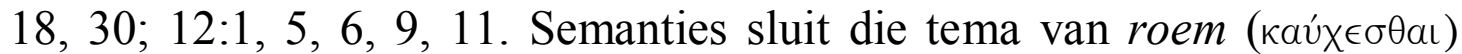

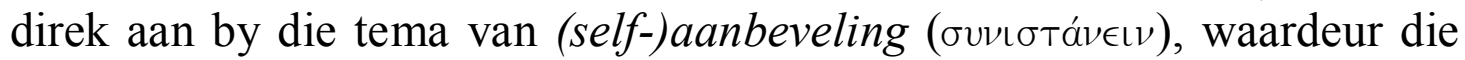
inherente eenheid van die brief nog verder versterk word.

Uit bostaande gegewens kan 2 Korintiërs se gedagtestruktuur soos volg saamgevat word (aangepas uit Lategan 1984:93-94; Guthrie, 1990:462-464; Coetzee, 1995:40): 
$1: 1-2$

$1: 3-11$

$1: 12-12: 21$

$1: 12-2: 11$

- $2: 12-13$

- $2: 14-7: 4$

$2: 14-4: 6$

$4: 7-5: 17$

$5: 18-7: 4$

$5: 11-21$

$6: 1-13$

\section{Briefaanhef}

Briefinleiding: Troos in Christus te midde van verdrukking

Briefliggaam: Praktiese bediening_van die apostel deur Titus

Paulus se veranderde reisplanne en die tranebrief

Begin van beskrywing van Titus se koms

Die doel en betekenis van Paulus se bediening

Die bediening van die nuwe verbond

Bediening vanuit verganklikheid na vernuwing

Die bediening van die versoening

6:14-7:1 Versoening met God = afsondering van ongeloof

7:2-4 Ruimte vir mekaar as versoendes

- 7:5-16 Voortsetting van die beskrywing van Titus se koms

- 8:1-9:15 Praktiese reëlings vir die insameling van bydraes deur Titus

10:1-12:21 Verdediging van Paulus se apostoliese gesag

$10: 1-18$ roem nie.

11:1-15 Valse apostels roem in hulleself

11:16-12:21 Paulus het in homself niks om oor te roem nie.

13:1-11 Afsluiting: Laaste vermanings

13:12-13 Briefslot

Bogenoemde struktuurontleding bevestig die vermoede dat Paulus in breë trekke vir die Korintiërs geskryf het oor sy praktiese bediening met Titus se hulp. Maar elke keer as sy eie apostoliese bediening ter sprake kom, het Paulus eers afgedwaal om breedvoeriger daaroor te skryf. Eers skryf hy oor die doel en betekenis van sy bediening (2:14-7:4), waarbinne hy besondere aandag gee aan die bediening van die versoening en dan keer hy weer stelselmatig terug na sy medelings oor Titus.

In ieder geval lyk dit of die perikoop 6:14-7:1 dan deel vorm van die Paulus se uiteensetting van die bediening van die versoening (vgl. Beale, 1989:550-581). Te midde van ander fasette van die bediening van die versoening, word in hierdie perikoop aangetoon dat versoening met God en met mekaar beteken dat daar geen gemeenskap met ongelowiges mag bestaan nie. Wie met God versoen is, kan nie nog bly vassit in allerlei goddelose verbintenisse nie.

Bogenoemde struktuurontledings gee dus 'n sterk aanduiding dat 2 Korintiërs 6:14-7:1 struktureel wel binne die geheelopset van die brief inpas en daarom as outentieke vermaning van die apostel Paulus aan die Korintiërs beskou kan word. 


\subsection{Die plek van 2 Korintiërs 6:14 binne die perikoop}

Uit bostaande struktuurontleding kan afgelei word dat 6:14 deel is van die perikoop wat strek van 6:14 tot 7:1. Ten einde die gedagtestruktuur van hierdie perikoop vas te stel, moet op die volgende struktuurmerkers gelet word:

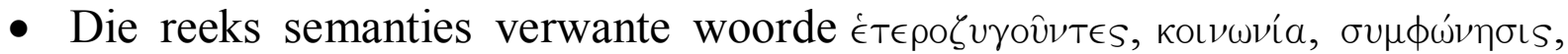
$\mu \in \rho l s$ en $\sigma \cup \gamma \kappa a \tau a ́ \theta \epsilon \sigma \iota s$ in verse 14 tot 16a wat almal binne die semantiese veld van "assosiasie" gebruik word (vgl. Louw \& Nida, 1988, semantiese domein 34). Hierdie reeks woorde dui op 'n moontlike samehang van verse 14 tot $16 \mathrm{a}$.

- Die reeks retoriese vrae in verse 14 tot 16 a wat eweneens hierdie verse tot een gedagte-eenheid saambind.

- Die trilogie van aanhalings uit die Ou Testament in verse $16 \mathrm{~b}$ tot 18 gee 'n aanduiding dat hierdie verse met mekaar saamhang.

- Meer op semantiese vlak is die samehang tussen die aanhalings in verse 16 en 18. Die werkwoorde van hierdie aanhalings is almal in die toekomende tyd, wat dui op die aard van 'n belofte. In 7:1 word inderdaad na die

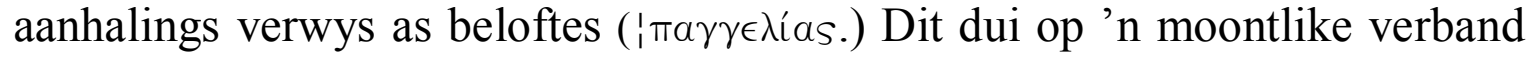
tussen hierdie verse.

Vanuit bogenoemde merkers blyk dit dan dat die gedagtes in 6:14-7:1 gestruktureer is in 'n ringkomposisie, waarvan die sentrale gedagte in die middelpunt voorkom. Dit kan ook 'n uurglas-patroon genoem word (vgl. Jordan, 1965:125):

$6: 14 \mathrm{a}$

$6: 14 b-16 a$

$6: 16 b$

$6: 16 c-18$
Opdrag tot heiligmaking: nie in dieselfde juk met ongelowiges nie Verbesondering van opdrag: retoriese vrae wat dui op geen gemeenskap tussen die heilige en die onheilige nie.

Sentrale gedagte:

Julle is die tempel van God.

Begronding in die O.T.:

Belofte dat God sal inwoon.

Opdrag tot afsondering van onheilighede

Belofte van die Vader dat ons sy kinders sal wees.

Op grond van God se beloftes, aansporing tot reiniging en heiligmaking in diens van God. 
Die uiteensetting van die Griekse teks sien soos volg daar uit:

$6: 14 a$

$6: 14 \mathrm{~b}$

$6: 14 \mathrm{c}$

$6: 15 \mathrm{a}$

$6: 15 b$

$6: 16 \mathrm{a}$

$6: 16 b$

$6: 16 \mathrm{c}$

$6: 17$

$6: 18$

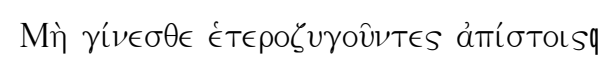

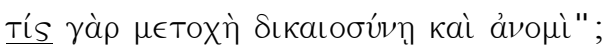

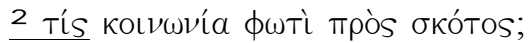

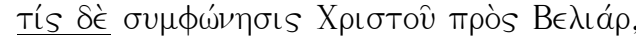

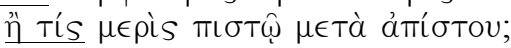

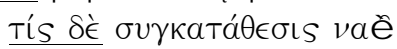

$\theta \in \mathrm{O} \hat{v} \mu \in T \grave{a} \in \hat{\imath} \delta \omega \dot{\lambda} \lambda \omega \nu$;

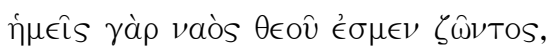

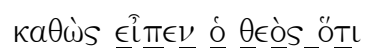

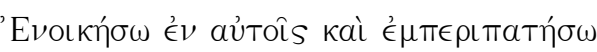

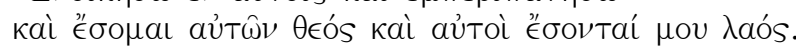

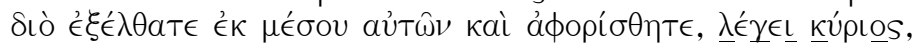

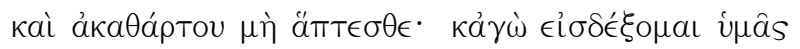

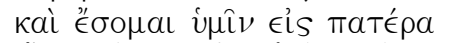

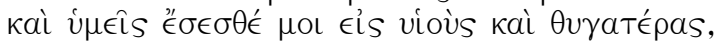

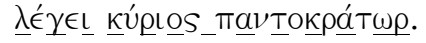

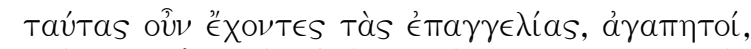

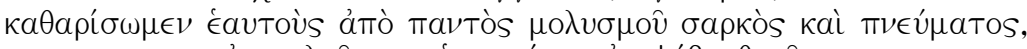

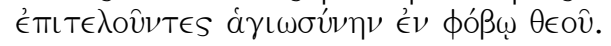

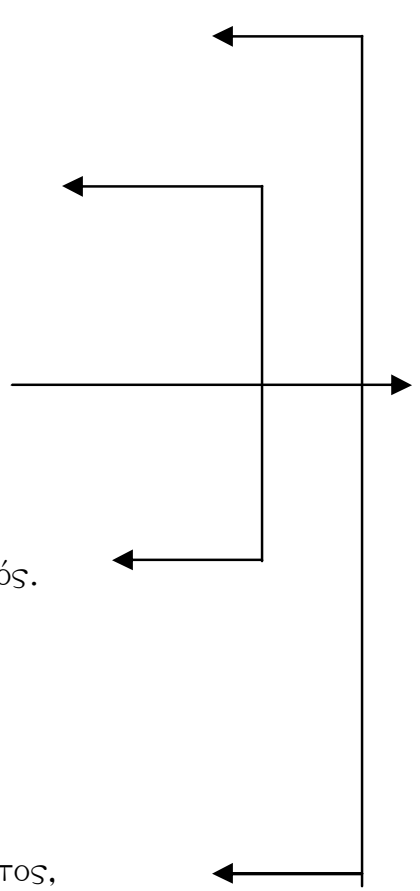

Uit bostaande struktuurontleding blyk dat die opdrag in 6:14a aansluit by die aansporing tot reiniging in $7: 1$. Hierdie aansporing word verbesonder in $6: 14 \mathrm{~b}-$ 16 a deur vyf retoriese vrae, elk op opvallende wyse ingelei deur die vraagwoord tís. Dat hierdie reeks retoriese vrae as verbesondering beskou kan word, blyk uit die inleidende $\gamma a ́ \rho$ in $14 \mathrm{~b}$. Verder word die aansporing in 6:16c-18 begrond in enkele Ou-Testamentiese aanhalings, saamgebind deur die drie aanhalings-

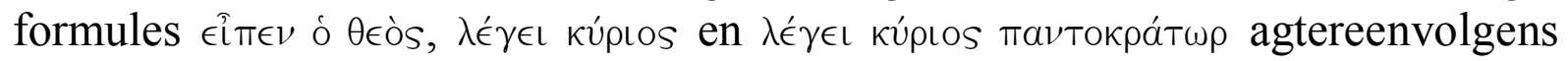
in verse 16, 17 en 18. Dat die aanhalings as begronding beskou kan word, blyk uit die inleidende ráp in vers $16 b$.

Die hele perikoop kan egter beskou word as 'n uitbouing van die sentrale gedagte: "Julle is die tempel van God." Vanuit hierdie sentrale gedagte is die res van die perikoop ' $n$ uiteensetting van hoe die gelowiges werklik as tempel van God behoort te leef. Die opdrag van 6:14 behoort dus gelees te word as 'n manier hoe om te streef na die reiniging en heiligmaking wat pas by die gelowige as tempel van God.

\subsection{Samevatting}

Belangrike gegewens wat deur die gedagtestruktuurontleding blootgelê is, is die volgende: 
- Die verbod van 6:14 vloei voort uit die heilsfeit van die versoening met God. Om met God versoen te wees, lê op die versoende die verantwoordelikheid van en roeping tot heiligmaking. Die heiligmaking sluit onder meer in afsondering van onheilige dinge, ook afsondering van ongelowiges.

- Afsondering van alles wat onheilig is, is verder nodig vanweë die feit dat die versoendes die tempel van God is.

- Ook God se beloftes dat Hy in die versoendes woon en hulle sy kinders maak, is grond vir die opdrag om nie deur onheilige dinge in beslag geneem te word nie.

\section{Sintaktiese en semantiese ontleding van 2 Korintiërs 6:14}

\subsection{Sintaktiese ontleding}

Ten einde nader deur te dring na die bedoeling van die woorde $\mathrm{m}^{\prime \prime}$ g\nesqe @erozugoÿntej ï plstoij is dit nodig om 'n sintaktiese ontleding van die sin te maak. Volgens die uiteensettingswyse van Van Rensburg (1986), is die sintaktiese samehang van die sin soos volg:

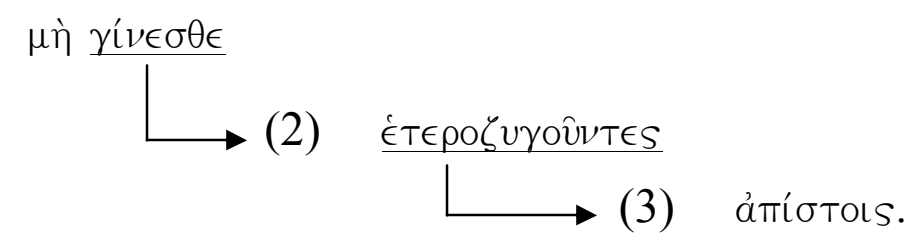

- $\mathrm{K} 1$ is die hoofwerkwoord van die sin. Dit is 'n koppelwerkwoord in die imperatief tweede persoon meervoud. Die onderwerp wat daarby inbegrepe is, is die tweede persoon "julle".

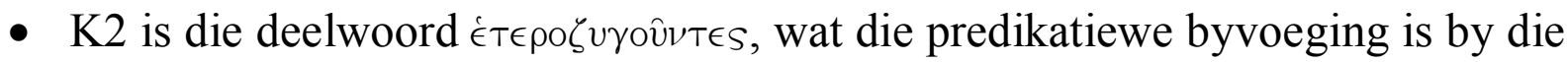
onderwerp van die koppelwerkwoord K1. Dit is van 'n onoorganklike werkwoord gevorm en as sodanig het dit nie 'n direkte voorwerp nie.

- $\mathrm{K} 3$ is 'n datiewe naamwoord wat K2 kwalifiseer, waarskynlik ten opsigte van assosiasie.

Die konstruksie $\mu^{\prime \prime}$ met die praesens imperatief $\gamma^{\prime} v \in \sigma \theta \in$ in die Nuwe Testament kan 'n verbod bevat (a) om nie iets te doen nie of (b) om nie daartoe oor te gaan om iets te doen nie (Blass \& Debrunner, 1975:173). Indien die semantiese gebruiksveld van die werkwoord rívouar ("wees", "word", vgl. Louw \& Nida, 1988:13.3 en 13.48) hierby in berekening gebring word, dui dit daarop dat die

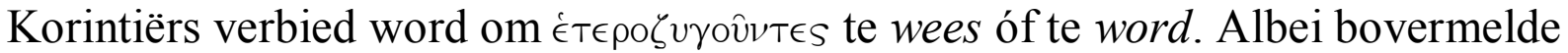
gebruike van $\mu^{\prime \prime}$ met die imperatief is dus in hierdie geval moontlik. 
Indien die woorde $\gamma^{\prime}(v \in \sigma \theta \epsilon \dot{\epsilon} T \epsilon \rho \circ \zeta v \gamma o v v \nu T \epsilon S$ egter as 'n soort perifrastiese praesens beskou word, beteken dit dat juis die duratiewe, voortgaande aspek van die handeling beklemtoon word: moet nie in 'n toestand wees waarin julle

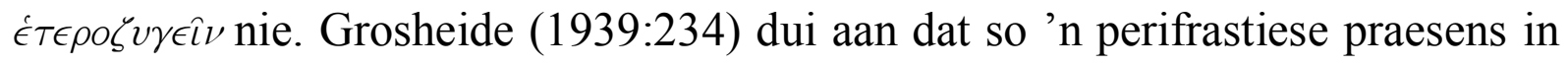

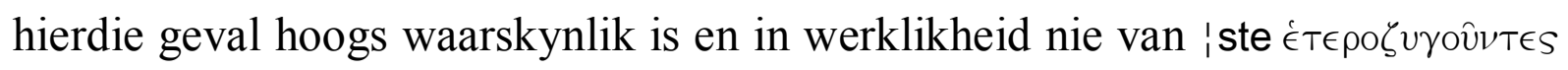
verskil nie. Derhalwe moet die eerste van bogenoemde gebruike van $\mu^{\prime \prime}$ met die imperatief verkies word, naamlik om (oor die algemeen) nie te є̇ $\epsilon \in \rho \zeta \zeta \gamma \in \hat{\imath} v$ nie. Dit wil dus voorkom asof Paulus nie maar net wil verhoed dat die Korintiërs tot bepaalde optrede oorgaan nie, maar dat hy sulke optrede oor die algemeen verbied. Die Korintiërs se leefwyse moet deurgaans so wees dat hulle by hierdie verbod hou.

\subsection{Semantiese ontleding}

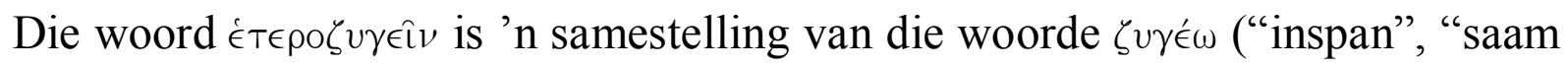
onder 'n juk inbring") en die byvoeglike naamwoord étépos ("ander") wat as voorvoegsel daarby gevoeg is. Die samestelling is dan gewoonlik gebruik in die sin van "om met 'n andersoortige dier saam in 'n juk in te span". Hierdie gebruik van die woord korreleer met die verbod in Deuteronomium 22:10: "Jy mag nie met 'n os en 'n esel tegelyk ploeg nie" (Link \& Brown, 1978: 1160).

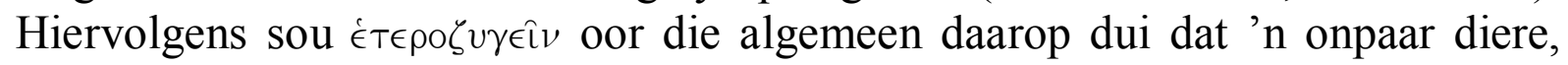
wat nie bymekaar pas nie, in dieselfde juk ingespan word (vgl. ook Rengstorf, 1978:901).

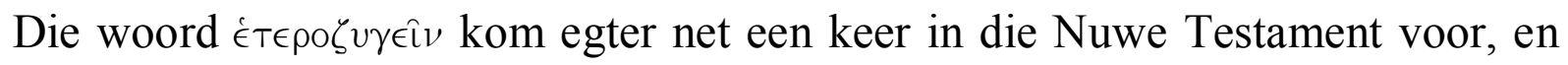
ook net een keer in buite-Bybelse literatuur (vgl. Link \& Brown, 1978:1160). Daarom is dit moeilik om 'n vergelykende studie te doen - ook met die kontemporêre gebruik van die woord.

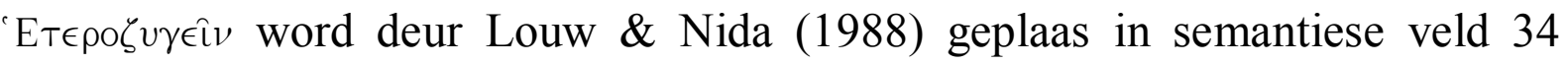
("Assosiasie"), binne subdomein A ("assosieer"). Ander woorde wat binne

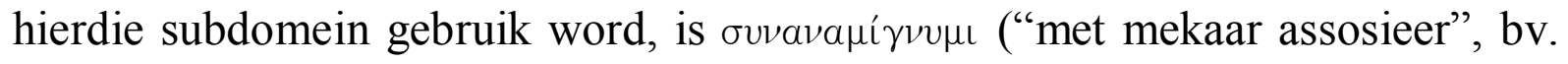

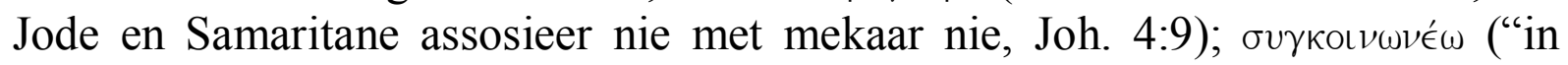

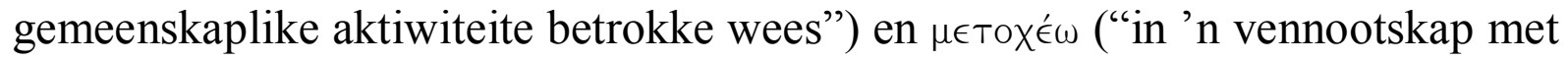
gemeenskaplike doel en aktiwiteite betrokke wees").

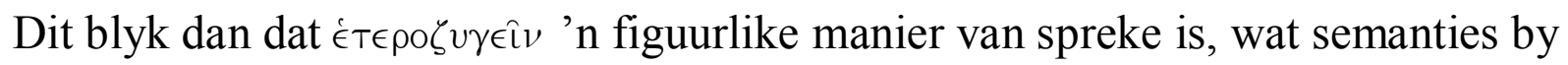
die gebruiksveld van bogenoemde woorde aansluit: "om te assosieer deur tot gemeenskaplike aktiwiteite en gemeenskaplike doelwitte aan mekaar verbind te

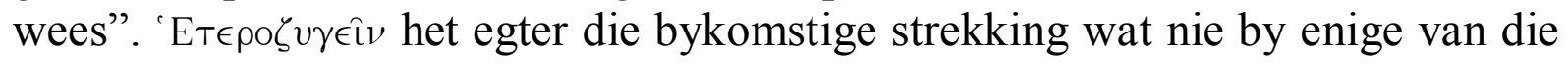
ander woorde teenwoordig is nie, naamlik die gedagte van 'n onpaar ( $\epsilon$ Tépos) wat assosieer en aan mekaar verbind is (vgl. Louw \& Nida, 1988: 34.9).

Hiermee word myns insiens nog nie voldoende rekenskap gegee van die gebruik van die voorvoegsel $\dot{t} \tau \in \rho-$ nie. Hierdie voorvoegsel beklemtoon die gedagte van 'n ander juk. Deur hierdie voorvoegsel word die rigting waarin die assosiasie 
plaasvind, gekwalifiseer as ' $\mathrm{n}$ assosiasie waarin iemand verbonde raak aan die ander persoon se aktiwiteite en doelwitte. Daarom is die gevolgtrekking van

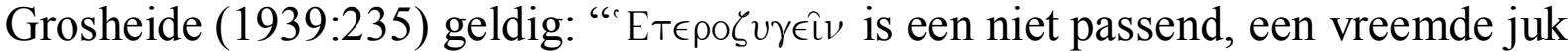
op zich nemen, eventueel een juk, waaronder reeds een ander (eie kursivering, GJCJ) dier loopt, waar het tweede niet bij hoort".

In die laaste plek moet die aanwending van die woord ảmíotors in 6:14 nagegaan word. Volgens Louw en Nida (1988) word ảmíбтoıs as selfstandige naamwoord gebruik met verwysing na iemand wat sonder geloof is, wat nie in Jesus Christus glo nie (subdomein 31.106). Die ámíotors (ongelowige) moet onderskei

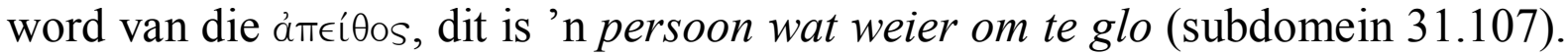
Daarom verwys ảmíoto nie na afgedwaalde of ontroue Christene nie maar na mense wat hulle heeltemal buite die kerk bevind, dit wil sê nie-Christene (subdomein 11.19; vgl. ook Plummer, 1948:206).

\section{Die Korintiërs se verstaan van "in een juk trek"}

\subsection{Die sosio-historiese konteks van die Korintiërs}

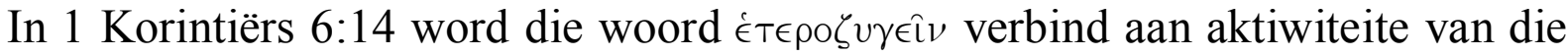
kerk in Korinte. Dit spreek dus vanself dat die lesers die woord nie letterlik (met verwysing na trekdiere) sou opneem nie, maar in figuurlike sin (met verwysing na mense). Verder sou hulle figuurlike inkleding van die mededeling wel ook ingebed wees in die sosio-historiese konteks waarbinne hulle dit verneem het.

'n Figuurlike of metaforiese gebruik van die woord sou nie vir die Korintiërs vreemd gewees het nie. Hulle was immers daaraan gewoond om die woord

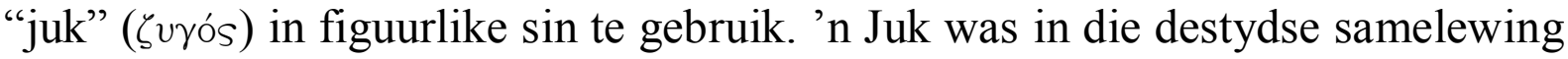
'n simbool van slawerny, onderworpenheid en ongehoorsaamheid. Dit word

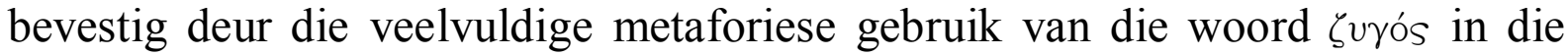
Nuwe Testament: In 1 Korintiërs 7:21 en 1 Timoteus 6:1 lees ons van die "juk van slawerny"; in Galasiërs 5:1 en Handelinge 15:10 gaan dit oor die "juk van slawerny aan die wet"; laasgenoemde gebruik is waarskynlik ook in Matteus 11:29 ter sprake waar Jesus sy "juk" sag noem.

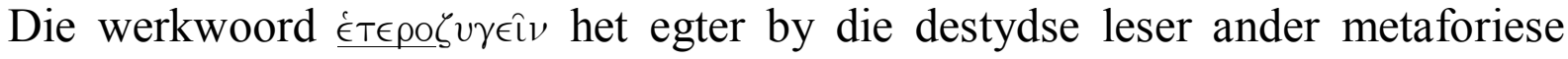
konnotasies opgeroep as dié van slawerny, onderworpenheid en gehoorsaamheid. Hierbo is reeds aangetoon dat die woord letterlik verwys na 'n onpaar wat saam trek (vgl. Louw \& Nida, 1988:34.9), of 'n trekdier wat in 'n ander juk, wat nie by hom pas nie, saam met 'n ander trek. Letterlik sou die woord gewoonlik verwys na 'n onpaar trekdiere.

Die gedagte van 'n onpaar trekdiere was blykbaar nie 'n ongewone verskynsel in Bybelse tye nie. Veral die armes was soms genoodsaak om verskillende soorte trekdiere saam in te span (Petersen, 1976:1023). So 'n saamtrekkery het egter skeeftrekkery en ongelyke werk tot gevolg gehad. Dit was moontlik 'n rede vir 
die verbod in Deuteronomium 22:10 dat jy nie met 'n os en 'n esel tegelyk mag ploeg nie (Petersen, 1976:1023). Die verbod was egter meer as net 'n praktiese reëling. Dit het ook 'n etiese kant gehad, naamlik dat 'n onpaar trekdiere die emosionele konnotasie van ontoelaatbare vermenging gedra het. Dit word bevestig deur 'n aanverwante verbod in Levitikus 19:19 (vgl. Rengstorf, 1978:901; Strack \& Billerbeck, 1969:521).

Vanuit die letterlike gebruik sou die leser dan die metaforiese gestalte aflei. Net soos ongelyksoortige diere 'n onpaar jukmaats vorm, so vorm ongelyksoortige mense 'n onpaar, wat as gevolg van hulle ongelyksoortigheid kwalik kan werk sonder "skeeftrekkery" en "ongelykheid" in hulle werk. Die emosionele konnotasie van ontoelaatbare vermenging wat aan 'n onpaar trekdiere verbind is, sou waarskynlik deur die Korintiërs ook in die metafoor ingedra gewees het.

Wie is figuurlik gesproke die "onpaar jukmaats" waarna Paulus in 6:14 verwys? By die Korintiërs sou daar geen twyfel wees nie. Aan die een kant is daar die

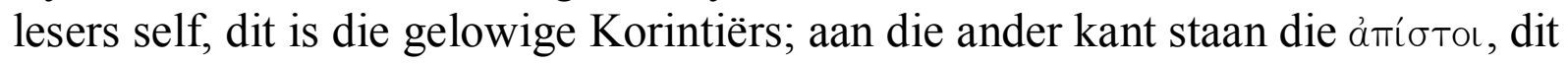
wil sê die nie-Christene waarmee hulle in Korinte te doen gekry het.

Die sosio-historiese milieu waarbinne Paulus die woorde van 6:14 aangebied

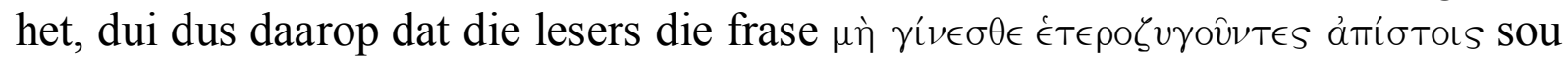
verstaan het as

- 'n metaforiese uitdrukking wat figuurlik verstaan moet word;

- 'n verbod waarin die verhouding tussen 'n gelowige en 'n ongelowige aangedui word as dié van 'n onpaar jukmaats;

- 'n aanduiding dat gelowiges en ongelowiges nie op gelyke vlak staan nie;

- 'n aanduiding dat die samewerking van gelowiges en ongelowiges 'n skeeftrekking van sake tot gevolg het;

- 'n aanduiding van ongeoorloofde vermenging.

\subsection{Die semantiese konteks van 1 Korintiërs 6:14}

Die Korintiërs se verstaan van die metaforiese $\dot{\epsilon} \tau \in \rho \circ \zeta \nu \gamma \in \hat{\imath} \nu$ is waarskynlik medebepaal deur die gevoelswaarde van die mededelings in die onmiddellike konteks van 2 Korintiërs 6:14. Veral die reeks retoriese vrae wat struktureel aan die opdrag in 6:14 verbind is (vgl. 2.3 hierbo) en by wyse van die partikel ráp naderverklarend aan die opdrag verbind is, behoort hierby in ag geneem te word.

Die vier selfstandige naamwoorde binne hierdie retoriese vrae $\mu \in T o \chi \eta ́, ~ \kappa o เ \nu \omega \nu i ́ \alpha, \sigma v \mu \phi \omega ́ \nu \eta \sigma \iota s$ en $\mu \in \rho i ́ s$ gee 'n aanduiding van die metoforiese verstaan van $\dot{\epsilon} \tau \in \rho \zeta \zeta \gamma \in \hat{\epsilon} \nu$. 
Die naamwoord $\mu \in т$ тох́ dui op "gemeenskaplike besit", "gesamentlike deelname" (Grosheide, 1939:236; Louw \& Nida, 1988:34.7), wat 'n geringe suggestie laat van ekonomiese aktiwiteit. Die retoriese vraag maak dit duidelik dat daar

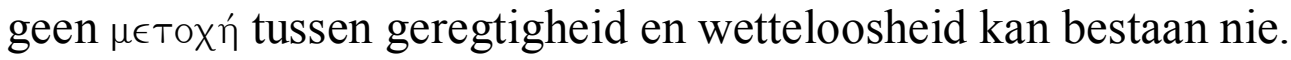

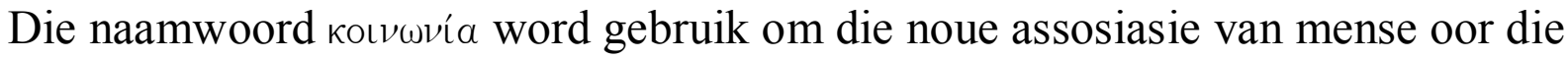
algemeen aan te dui (Louw \& Nida, 1988:34.5). Die retoriese vraag stel dat daar tussen lig en duisternis geen $\mu \in T$ то metaforiese sin verstaan behoort te word, blyk daaruit dat dit by herhaling in die Bybel gebruik word in verwysings na "gelowiges" en "ongelowiges" (bv. Matt. 5:14; Ef. 5:7-11; Joh. 8:12; Hand. 26:18). Die gevoelswaarde hiervan is dat gelowiges en ongelowiges net so min as lig en donker in 'n noue verbintenis met mekaar kan staan. Waar die lig intree, daar wyk die donker, en andersom (vgl. Grosheide, 1939:236).

In vers 15 word die woord $\sigma u \mu \phi \omega ́ v \eta \sigma \iota s$ gebruik. Volgens Louw en Nida word die woord gebruik binne die betekenisveld van "gesamentlike besluitneming" (Louw \& Nida, 1988:31.15). Grosheide (1939:236) wys daarop dat die woord die gevoelswaarde het van "uit een mond praat". Christus en Belial sal nooit uit een mond praat nie. Die implikasie is: desgelyks kan gelowiges en ongelowiges nooit uit een mond praat nie.

Oor die assosiasies wat die naam "Belial" by die destydse gelowiges opgeroep het, wys Feinberg (1976:513) daarop dat die betekenis van Belial (oftewel "Beliar" volgens die grondteks) in die Talmud aangegee word as "sonder juk", wat neerkom op "bandeloosheid" en eventueel "goddeloosheid". Latere Joodse geskrifte gebruik die naam Belial in verwysings na Satan of selfs die pseudoMessias (die antichris, vgl. Grosheide, 1939:237). Net so min as wat Christus en die antichris uit een mond sal praat, net so min kan gelowiges en ongelowiges uit een mond praat of in hulle doen en late eendragtig wees

Die naamwoord $\mu \epsilon$ ís in vers 15 word ook oor die algemeen gebruik in die betekenis van "deel van 'n geheel", oftewel "aandeel". Dit kan op ekonomiese, sosiale, godsdienstige of selfs politieke gebied van toepassing gemaak word (vgl. Louw \& Nida, 1988:63:11).

Die semantiese konteks van 2 Korintiërs 6:14 dui dus daarop dat die verbod in hierdie vers deur die eerste lesers verstaan sou word as 'n eendragtige optrede op ekonomiese, sosiale en ten minste ook op godsdienstige gebied.

\section{Draagwydte en implikasies van die verbod}

\subsection{Sintese}

Uit die bespreking hierbo blyk dat die draagwydte van die verbod in 2 Korintiërs 6:14 soos volg saamgevat kan word: 
- Die verbod van 6:14 vloei voort uit die heilsfeit van die versoening met God. Om met God versoen te wees, lê op die versoende die verantwoordelikheid van en roeping tot heiligmaking. Die heiligmaking sluit onder meer in afsondering van onheilige dinge, ook afsondering van ongelowiges.

- Afsondering van alles wat onheilig is, is verder nodig vanweë die feit dat die versoendes die tempel van God is.

- Ook God se beloftes dat Hy in die versoendes woon en hulle sy kinders maak, is grond vir die opdrag om nie deur onheilige dinge in beslag geneem te word nie.

- Daarom is 'n gelowige en 'n ongelowige in figuurlike sin onpaar jukmaats wat nie met die oog op 'n gemeenskaplike doel in gemeenskaplike aktiwiteite aan mekaar verbonde mag wees nie.

- Sodanige gemeenskaplike aktiwiteite bring 'n ongelykheid voort wat lei tot 'n skeeftrekking van sake.

- Wat spesifiek ongeoorloof is, is dat gelowiges by die aktiwiteite van ongelowiges betrokke raak. Klaarblyklik is dit in orde om ongelowiges by die aktiwiteite van gelowiges te betrek. Maar die omgekeerde is ontoelaatbaar.

- Die opdrag van 6:14 is nie net tot die Korintiërs beperk nie, maar is bedoel vir gelowiges van alle tye. Dit blyk uit die feit dat

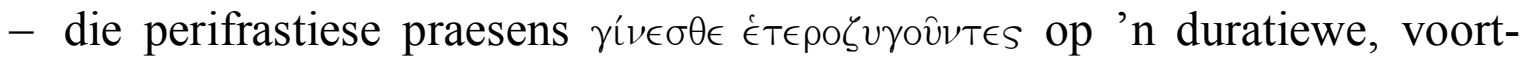
gaande handeling dui wat in die algemeen gestel is;

- die verbod gegee word as deel van die uiteensetting van die bediening van versoening. Hierdie bediening was nie beperk tot dié van die apostel Paulus aan die Korintiërs nie, maar word gegee as deel van die tipering van die apostoliese bediening oor die algemeen.

\subsection{Skrif-met-Skrif-vergelyking}

Die draagwydte en implikasies van die verbod in 6:14 word duideliker omlyn wanneer dit by wyse van Skrif-met-Skrif-vergelyking naas ander Skrifdele geplaas word wat oor dieselfde of aanverwante sake handel. Die volgende blyk van belang te wees.

\subsubsection{Nie 'n opdrag tot asketiese leefwyse nie}

Hierbo is meermale daarop gewys dat die verbod in 6:14 deel vorm van die opdrag tot heiligmaking van die gelowiges; ook dat die opdrag behels dat die 
gelowige hom moet afsonder van alles wat onheilig is, in hierdie geval van ongelowige mense. Dit sou maklik vertolk kon word as 'n opdrag tot wêreldontvlugting.

Dat die verbod nie so vertolk mag word nie, blyk uit wat Paulus vantevore aan die Korintiërs geskryf het in 1 Korintiërs 5:9-13 (die gedeelte waarin hy na sy eerste, verlore, brief aan die Korintiërs verwys). In hierdie Skrifdeel stel Paulus dit baie duidelik dat sy bedoeling nie is dat die gelowiges hulle uit die wêreld moet onttrek of daarvan moet afsonder nie, "want dan sou julle uit die wêreld moet uitgaan" (1 Kor. 5:10).

Daarom moet die verbod van 6:14 nie verstaan word as 'n opdrag om hoegenaamd niks met ongelowiges te doen te hê nie. Inteendeel, die gelowige durf nie kontak met ongelowiges vermy nie. Christus het immers aan sy kerk die opdrag gegee om na die heidene te gaan en die evangelie aan hulle te verkondig (Matt. 28:18). 2 Korintiërs 6:14 is dus nie 'n opdrag tot askese nie maar eerder ' $n$ verbod op aktiwiteite wat gelowiges en ongelowiges gesamentlik aangaan met die oog op 'n gemeenskaplike doel.

\subsubsection{Verbod op huwelike tussen gelowiges en ongelowiges}

Dit spreek vanself dat die verbod van 6:14 van toepassing is op die huwelik. In die huwelik is man en vrou tog op die mees intieme wyse as 'n paar saam "ingespan". Daarom sou 6:14 wel beskou kon word as 'n verbod op huwelike tussen gelowiges en ongelowiges. So 'n verbod is dan ook in ooreenstemming met die opdrag aan Israel in die $\mathrm{Ou}$ Testament om nie met die heidene te ondertrou nie (vgl. Deut. 7:3, 4).

Nogtans kan die verbod van 6:14 nie as 'n opdrag tot totale afsondering beskou word nie. Hierdie perspektief word gegee vanuit 1 Korintiërs 7:12-16. Daar skryf Paulus dat 'n gelowige man, as hy 'n ongelowige vrou het, haar nie moet verstoot nie; net so ook 'n gelowige vrou nie haar ongelowige man nie (1 Kor. $7: 12,13)$. As motivering hiervoor bied Paulus die moontlikheid dat die gelowige dalk die ongelowige huweliksmaat tot geloof kan bring (1 Kor. 7:16). Ten spyte van so 'n moontlikheid gee die apostel toe dat 'n gelowige en 'n ongelowige saam in die huwelik 'n onpaar vorm. Daarom is egskeiding in so 'n geval wel toelaatbaar (1 Kor. 7:15).

Hieruit volg dat 2 Korintiërs 6:14 wel die gelowiges verbied om met ongelowiges 'n huwelik aan te gaan. As hulle dit sou doen, begewe hulle hulle willens en wetens in 'n ongelyke verhouding wat uit die staanspoor gedoem is om skeef te loop. 


\subsubsection{Arbeidsverhoudinge tussen gelowiges en ongelowiges}

In die Bybel is daar geen direkte verwysing na die wenslikheid van 'n gelowige om arbeids- of handelsbetrekkinge met ongelowiges aan te gaan nie. 'n Swygargument kan wel gehaal word uit die enkele insidente wat beskryf is van Romeinse soldate wat tot geloof gekom het. Die bekendste voorbeelde is die Romeinse offisier van Kapernaum (Luk. 7:1-10), Cornelius (Hand. 10) en die tronkbewaarder van Filippi (Hand. 16:27-36). Die swygargument bestaan daarin dat in nie een van die vermelde (of ander) gevalle daar enige aanduiding is dat van die soldate verwag is om van beroep te verander nie. In alle waarskynlikheid het hulle na hulle bekering steeds aangehou werk in die kring van ongelowige soldate waar hulle voorheen gewerk het.

Waarskynlik geld dieselfde beginsel by arbeidsverhoudinge as wat by huweliksverbintenisse gegeld het. Die gelowige moet nie arbeids- of handelsbetrekkinge vermy as dit hom met ongelowiges in aanraking bring nie. Inteendeel, hy/sy behoort die kontak te gebruik as 'n geleentheid om die evangelie van Christus aan die ongelowiges te bring.

Terselfdertyd moet die gelowige daarop bedag wees om hom/haar nie willens en wetens in 'n arbeidsituasie te begewe waarin hy/sy deur gemeenskaplike aktiwiteite en gemeenskaplike doelstellings so aan ongelowiges verbind word dat hulle later met mekaar assosieer nie. Assosiasie lei tot 'n ongelyke jukpaar wat 'n wanbalans tot gevolg het en tot ongeoorloofde vermenging van oortuigings kan lei.

\subsubsection{Geen samewerking op godsdienstige gebied nie}

Wanneer 2 Korintiërs 6:14 vergelyk word met 1 Korintiërs 10:14-22, blyk dat die verbod om nie in dieselfde juk met ongelowiges te trek nie, beslis ook op godsdienstige gebied van toepassing is.

Stilisties en inhoudelik het 1 Korintiërs 10:14-22 baie in gemeen met 2 Korintiërs 6:14-17. Net soos in 2 Korintiërs 6:14-17, neem die begrip

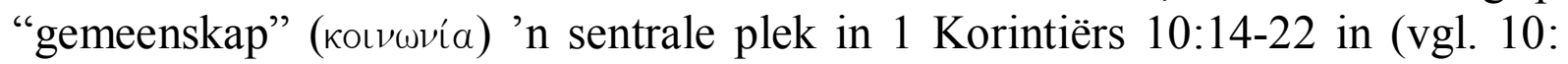
$16,16,17,18,20,21)$. Daarby word die gemeenskapsaspek, net soos in 6:14-17, deur 'n reeks retoriese vrae beklemtoon in 10:16-18. Boonop word 10:14-22 ingelei met die sterk opdrag: "Daarom, my geliefdes, vlug vir die afgodediens", wat sterk ooreenkom met 6:17: "Daarom, gaan onder hulle uit en sonder julle af, spreek die Here".

1 Korintiërs 10:14-22 is egter 'n direkte en duidelike afwysing van enige samewerking met ongelowiges op godsdienstige terrein. Teen hierdie agtergrond kan aanvaar word dat ook die verbod om met gelowiges in dieselfde juk te trek, beslis op godsdienstige bedrywighede van toepassing is. 
Uit 1 Korintiërs 10:14-22 blyk dat dit onaanvaarbaar is vir Christene om saam met nie-Christene aan dieselfde offermaaltyd of soortgelyke godsdienstige seremonies deel te hê. Aangesien daar 'n noue band tussen offermaaltye en gebede bestaan het (vgl. Rainey, 1976:195), kan die afleiding gemaak word dat gelowiges ook nie met ongelowiges saam mag aanbid nie.

\section{Situasie-analise in Suid-Afrika en toepassing}

\subsection{Situasie-analise}

Uiteraard is die huidige situasie in Suid-Afrika in vele opsigte anders as wat destyds in Korinte die geval was. Anders as Korinte destyds, is die Christelike godsdiens in Suid-Afrika 'n gevestigde godsdiens, tot so 'n mate dat dit selfs as die toonaangewende godsdiens beskou kan word. Dit beteken egter nie dat die hele Suid-Afrikaanse samelewing as Christelik bestempel kan word nie. In SuidAfrika, soos in die destydse Korinte, bevind Christene en nie-Christene hulle in dieselfde maatskaplike leefruimte, onder 'n nie-Christelike owerheid.

Christene in Suid-Afrika het dus in hulle daaglikse omgang gereeld met ongelowiges te doen. Kontak tussen gelowiges en ongelowiges vind onder meer plaas op sakegebied, in arbeidsverhoudinge, op politieke terrein en ook op godsdienstige terrein. Selfs huwelike tussen gelowiges en ongelowiges is nie vreemd aan die Suid-Afrikaanse opset nie. Daarom is dit vir Christene in SuidAfrika nodig om prinsipieel leiding te ontvang oor hulle verhouding met nieChristene en hoe om in die praktyk teenoor nie-Christene op te tree.

In die voorgaande bespreking is aangetoon dat gelowiges destyds in Korinte in wese met hierdie selfde vraagstukke geworstel het. Juis binne hierdie problematiek het die apostel Paulus die verbod van 2 Korintiërs 6:14 aan hulle gerig. Gevolglik bied hierdie verbod ook vir Christene in Suid-Afrika die norm vir optrede jeens nie-Christene.

\subsection{Toepassing}

As algemene norm vir optrede vir gelowiges in Suid-Afrika geld die beginsel wat in 2 Korintiërs 6:16 gestel is, naamlik dat elke gelowige tempel van God is. As sodanig moet die gelowige se leefwyse heilig wees - ánders as die leefwyse van ongelowiges.

Die metaforiese juk waarin die gelowige trek, mag dus geen ander juk wees nie as die juk van diensbaarheid aan die koninkryk van God en van gehoorsaamheid aan sy liefdesgebod. Gelowiges mag in geen ander juk as die juk van Christus trek nie. Die juk waarin ongelowiges trek, mag gelowiges hoegenaamd nie op hulle neem nie. Gelowiges is immers die tempel van God. 
Vanuit die voorgaande eksegese blyk dit dan dat die algemene heilige lewenswyse van gelowiges in Suid-Afrika soos volg verbesonder moet word:

\subsubsection{Nie wêreldonttrekking nie}

Hoewel gelowiges se lewe anders as dié van ongelowiges in Suid-Afrika moet wees, beteken die verbod van 2 Korintiërs 6:14 nie dat daar geen kontak met ongelowiges mag plaasvind nie. Die bedoeling is nie dat gelowiges uit hierdie wêreld moet uitgaan nie (vgl. 5.2.1 hierbo). Wêreldontvlugting is ook nie moontlik nie, aangesien gelowiges en ongelowiges in Suid-Afrika op dieselfde leefruimte aangewese is. Almal asem dieselfde lug in; almal worstel met dieselfde probleme van misdaad, geweld en rassespanning.

Te midde van hierdie saamwees in Suid-Afrika, moet Christene egter steeds toon dat hulle heilige tempels van God is deur nie met nie-Christene gemeenskap te beoefen of met hulle te fraternaliseer nie. Enersyds nie wêreldontvlugting nie; andersyds nie wêreldgelykvormigheid nie.

\subsubsection{Sendingtaak}

Wanneer Christene dan nie-Christene opsoek, moet dit wees ter eventuele uitvoering van die opdrag van die Here om die evangelie aan almal te verkondig (vgl. 5.2.1 hierbo). Die sendingopdrag noop Suid-Afrikaanse Christene dan om die hand na nie-Christene in Suid-Afrika te reik deur die verlossingsboodskap aan hulle te verkondig. In metaforiese taal gestel: ongelowiges moet sover gebring word om saam met gelowiges in die juk van Jesus Christus te trek.

\subsubsection{Nie godsdienstige samewerking nie}

Sonder enige twyfel beteken die verbod van 2 Korintiërs 6:14 dat gelowiges nie in die godsdienstige juk van ongelowiges mag trek nie. Met ander woorde: Christene mag nie meedoen aan enige godsdientige aktiwiteite van nie-Christene nie. Die implikasies hiervan is dat Christene hulle moet onttrek aan geleenthede waar enige eer aan afgode bewys word. Dit sluit in geleenthede waarby tot enige afgod gebid word.

'n Oënskynlik grys gebied is multi-gebedsgeleenthede. In die poging om verskillende gemeenskappe in Suid-Afrika "nader aan mekaar te bring" is daar reeds by verskeie geleenthede, byvoorbeeld die Kodesa-byeenkoms van 1994, verteenwoordigers van verskillende godsdienste byeengebring om elk tot "sy eie god" te bid. Christene wat daarby betrokke raak, mag dit dalk as 'n geleentheid beskou om te midde van 'n veelheid van valse godsdienste vir die waarheid te getuig. Ongelukkig bied sulke multi-gebedsbyeenkomste in praktyk nie geleentheid vir Christene om sending te doen nie. Veel eerder dra die meewerking aan sulke byeenkomste die boodskap uit dat die Christelike godsdiens maar net een van vele godsdienste is, 'n boodskap waarmee die heiligheid van 
God (6:15) en die heiligheid van sy tempel (6:16) nie versoen kan word nie. Om aan sulke praktyke mee te doen, loop dus ongelukkig daarop uit dat gelowiges in 'n "ander" juk gaan trek, 'n juk wat nie by gelowiges pas nie.

Die praktiese implikasies van 2 Korintiërs 6:14 is dus dat gelowiges op godsdienstige terrein op geen manier met ongelowiges mag saamwerk nie (vgl. 5.2.4 hierbo), ook nie in 'n multi-godsdienstige Suid-Afrika nie.

\subsubsection{Huwelike}

Hierbo in 5.2.2 is reeds aangetoon dat die verbod in 2 Korintiërs 6:14 impliseer dat 'n gelowige nie 'n huwelik met 'n ongelowige mag aangaan nie. Hierdie opdrag bly geld vir elke gelowige, ook in Suid-Afrika vandag. Juis deur sulke huweliksverbintenisse af te wys, word die heiligheid van die gelowige as tempel van God sigbaar gedemonstreer.

In Korinte het dit destyds waarskynlik dikwels gebeur dat in reeds bestaande huwelike (tussen ongelowiges) een van die twee huweliksmaats tot geloof gekom het. In Suid-Afrika kom so 'n huweliksopset minder algemeen voor. Waar dit tog voorkom, behoort so 'n huwelik van krag te bly, op die moontlikheid af dat die ongelowige huweliksmaat deur die voorbeeld en invloed van die gelowige huweliksmaat met verloop van tyd tot geloof gebring kan word (vgl. 5.2.2 hierbo). Om by voorbaat in 'n huwelik met 'n ongelowige in te gaan, is en bly egter steeds ontoelaatbaar vir gelowiges.

\subsubsection{Arbeids- en sakeverhoudings}

Aangesien gelowiges in hierdie wêreld woon en werk, is dit onvermydelik dat hulle in die arbeids- of sakewêreld in situasies verkeer waarby ongelowiges betrokke is. Sulke situasies behoort nie vermy te word nie, maar moet gebruik word as 'n geleentheid om vir die waarheid aangaande Christus te getuig (vgl. 5.2.3 hierbo).

Gelowiges moet egter bedag wees op arbeids- of sakegeleenthede wat op nieChristelike oortuigings gevestig is. Werksomstandighede wat die verering van afgode verg, of wat tot praktyke lei wat teen 'n Christelike leefwyse indruis, of wat dit onmoontlik maak om die heerskappy van God te erken, is vir gelowiges 'n "vreemde juk" waarin hulle nie mag saamtrek nie. Daarom behoort arbeidsen sakegeleenthede wat verband hou met casino's, waarsêery, sangomapraktyke, prostitusie, dwelm- en drankmisbruik en ander soortgelyke praktyke deur gelowiges vermy te word. 'n Gelowige sal ook weier om boeke, video's, musiekopnames of enige materiaal te verhandel wat in enige opsig die eer van God aantas of wat eer aan enige afgod of aan Satan self toebring.

Arbeid op Sondae besorg vir baie gelowiges in Suid-Afrika hoofbrekens. In die reël sal gelowiges weier om sake te bedryf wat Sondagarbeid vereis. Nood- 
saaklike Sondagarbeid is natuurlik 'n uitsondering. Die huidige klimaat in SuidAfrika is egter só ten gunste van Sondagarbeid dat selfs nie-noodsaaklike arbeid op Sondae verrig word. In hierdie opsig is gelowiges, ook in die lig van 2 Korintiërs 6:14, geroepe om 'n getuienis in die samelewing te laat uitgaan deur nie in die vreemde juk van nie-noodsaaklike Sondagarbeid mee te doen nie.

\subsubsection{Politieke terrein}

Die Suid-Afrikaanse samelewing het in die afgelope aantal jare erg verpolitiseerd geraak. Feitlik elke terrein van die lewe is onder die heerskappy van die politiek ingetrek. Verpolitisering van die samelewing staan lynreg teenoor die Skrifopenbaring, wat dit duidelik maak dat elke terrein van die lewe onder die heerskappy van God staan. Gelowiges is daarom geroepe om nie in die ongelowige juk van verpolitisering saam te trek nie maar om te getuig van God se heerskappy op elke lewensterrein, ook op politieke terrein.

Die konsekwensies hiervan is egter nie dat gelowiges hulle van die politiek van die tydsgewrig moet distansieer nie. Betrokkenheid by politieke prosesse en politieke partye van die tyd is noodsaaklik. Op grond van die vermaning van 2 Korintiërs 6:14 sal gelowiges egter seker maak dat die partye en prosesse waarby hulle betrokke raak, ten opsigte van grondslag, beleid, strewes en ook styl die toets van die Christelike oortuigings op grond van die Skrif sal slaag. By politieke partye met 'n nie-Christelike grondslag of strewes mag 'n gelowige nie aansluit nie.

Wat nie-Christelike owerhede betref, moet Christene bereid wees om hulle aan die gesag van die owerhede te onderwerp. As 'n gelowige 'n nie-Christelike owerheid gehoorsaam, beteken dit nie dat hy in 'n vreemde juk trek nie. Gehoorsaamheid aan die owerhede, ook nie-Christelike owerhede, is immers deel van die juk wat die Here ons oplê (vgl. Rom. 13:7 e.v.). Wanneer 'n owerheid egter aan sy onderdane eise stel wat teen die wil van God indruis, dan word gelowiges voor 'n keuse gestel. Dan is dit óf die juk van God (gehoorsaamheid aan God) óf 'n ander, vreemde juk. En, leer 2 Korintiërs 6:14, ons mag nie bereid wees om in 'n ander juk te trek nie.

\section{Samevatting}

Die verbod van 2 Korintiërs 6:14 gee 'n belangrike reëling vir gelowiges wat hulle in dieselfde leefruimte as ongelowiges bevind, ook vir gelowiges in SuidAfrika vandag. Dit is 'n allesomvattende verbod wat op elke lewensterrein vir die gelowige 'n orde aandui.

Hoewel die verbod geen wêreldontvlugting vereis nie, stel dit tog die noodsaak daarvan dat gelowiges in hierdie wêreld ' $n$ heilige lewe sal lei waarin hulle nie met heidendom en ongeloof saamgaan nie, maar hulle aan slegs God se heerskappy onderwerp. Daarom sal gelowiges nie meedoen aan enige praktyke 
waarin God se eer aangetas word of teen sy wil in opgetree word nie. Ook enige optrede wat vereenselwiging met heidense strewes en doelstellings verg, sal deur gelowiges vermy word. Dit geld onder meer vir die terrein van die godsdiens, die huwelik, arbeid, handel en die politiek.

In geheel bevat hierdie verbod die positiewe opdrag dat gelowiges van elke geleentheid gebruik sal maak om die evangelie van Jesus Christus aan ongelowiges te verkondig. En die weiering om aan Godonterende praktyke of ideale mee te doen, is 'n uiters positiewe getuienis hiervan.

\section{Bronnelys}

BEALE, G.K. 1989. The Old Testament background of reconciliation in 2 Corinthians 5-7 and its bearing on the literary problem of 2 Corinthians 6:1-7:1. New Testament Studies, 35:550-581.

BLASS, F. \& DEBRUNNER, A. 1975. A Greek grammar of the New Testament and other early Christian literature. Translated and revised by R.W. Funk. Chicago : University Press.

CALVIN, J. 1979. Commentary on the epistles of Paul the apostle to the Corinthians. Translated from the original Latin, and collated with the author's French version. Grand Rapids : Baker.

CARREZ. M. 1986. La deuxième épitre de Saint Paul aux Corinthiens. Commentaire du Nouveau Testament. Genève : Labor et Fides.

COETZEE, J.C. 1988. Gedagtestruktuurontleding en die eksegese van die Heilige Skrifte. (In Coetzee, J.C., red. Koninkryk, Gees en Woord. Pretoria : NG Kerkboekhandel. p.1937.)

COETZEE, J.C. 1995. Route map to the Books of the New Testament. Orkney : EFJS.

DUFF, P.B. 1993. The mind of the redactor: 2 Cor. 6:14-7:1 in its secondary context. Novum Testamentum, XXXV (2):160-180.

FEINBERG, C.L. 1976. Belial. (In Tenney, M.C., ed. The Zondervan Pictorial Encyclopedia of the Bible, I. Grand Rapids : Regency. p. 513.)

FILSON, F.V. \& REID, J. 1953. The second epistle to the Corinthians. The Interpreter's Bible X:263-425. New York : Abingdon.

GROSHEIDE, F.W. 1939. De tweede brief van den apostel Paulus aan de kerk te Korinthe. Kommentaar op het Nieuwe Testament. Amsterdam : Bottenburg.

GROSHEIDE, F.W. 1974. Paulus' tweede brief aan de kerk te Korinthe. Korte verklaring der Heilige Schrift. Kampen : Kok.

GUTHRIE, D. 1990. New Testament introduction. Illinois : Intervarsity Press.

JORDAN, J.E. 1965. Using rhetoric. New York : Abingdon.

KRUZE, C. 1991. The second epistle of Paul to the Corinthians. The Tyndale New Testament Commentary. Grand Rapids : Eerdmans.

KÜMMEL, W.G. 1972. Introduction to the New Testament. London : SCM Press.

LATEGAN, B.C. 1984. 2 Korintiërs. (In Du Toit, A.B., red. Handleiding by die Nuwe Testament V. Pretoria : NG Kerkboekhandel. p. 80-94.)

LINK, H.G. \& BROWN, C. 1978. Yoke. (In Brown, C., ed. The New international dictionary of New Testament Theology, III. Exeter : Paternoster. p. 1160-1165.)

LOUW, J.P. \& NIDA, E.A. 1988. Greek-English lexicon of the New Testament based on semantic domains. 2 vols. New York : United Bible Societies.

MEYER, H.A.W. 1879. Critical and exegetical handbook to the epistles to the Corinthians. Edinburgh : Clark. 
PETERSEN, L.M. 1976. Yoke. (In Tenney, M.C., ed. The Zondervan Pictorial Encyclopedia of the Bible, V. Grand Rapids : Regency. p. 1022-1023.)

PLUMMER, . 1948. A critical and exegetical commentary on the second epistle of St. Paul to the Corinthians. The International Critical Commentary. Edinburgh : Clark.

RAINEY, A.F. 1976. Sacrifice and offerings. (In Tenney, M.C., ed. The Zondervan Pictorial Encyclopedia of the Bible, V. Grand Rapids : Regency. p. 195-210.)

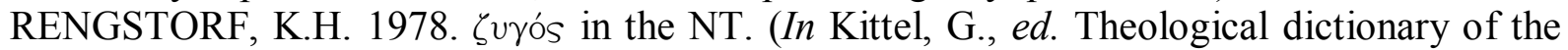
New Testament, II. Grand Rapids : Eerdmans. p. 898-901.)

SASS, G. 1993. Noch einmal: 2 Kor 6,14-7,1: Literarkritische Waffen gegen eine "unpaulinischen" Paulus? Zeitschrift für neutestamentlichen Wissenschaft, 84:36-64.

STRACK, H.L. \& BILLERBECK, P. 1969. Kommentar zum Neuen Testament aus Talmud und Midrasch, III. München : Beck

VAN RENSBURG, J.J.J. 1986. Гранца́тıкоs: 'n handleiding by grammatiese eksegese van die Griekse Nuwe Testament. Potchefstroom : Wesvalia.

WOLFF, C. 1989. Der zweite Brief des Paulus am die Korinther. Theologischer Handkommentar. Berlin : Evangelische Verlagsanstalt. 